\title{
The Analysis of Hypothesis Testing on Rare Sugars in Kagawa Prefecture
}

\author{
Hiromasa Takeyasu ${ }^{1}$, Yuki Higuchi ${ }^{2}$, Masazumi Tanaka ${ }^{1}$, Yumiko Matsushita ${ }^{1}$, Kazuhiro Takeyasu ${ }^{3}$ \\ ${ }^{1}$ Kagawa Junior College, Japan \\ ${ }^{2}$ Setsunan University, Japan \\ ${ }^{3}$ Tokoha University, Japan \\ Correspondence: Kazuhiro Takeyasu, College of Business Administration, Tokoha University, Shizuoka \\ 417-0801, Japan.
}

Received: October 8, 2017

doi:10.5539/ibr.v10n12p123

\author{
Accepted: October 30, $2017 \quad$ Online Published: November 8, 2017 \\ URL: https://doi.org/10.5539/ibr.v10n12p123
}

\begin{abstract}
The Rare Sugars exist naturally and have many kinds (more than 50). They have good effect for health such as prevention of increasing the blood - sugar level after eating, suppression of fat accumulation, suppression of increasing the blood pressure, and anti-oxidative effect etc. It is in the spotlight for many people especially for those who are in the metabolic syndrome. The Rare Sugars are prevailing in Japan by such activities as cooking class where the Rare Sugars are utilized for the new cuisine. There are few related papers concerning the marketing research and its utilization of this matter. In this paper, a questionnaire investigation is executed to the student of Kagawa Junior College in order to clarify consumers' current condition and their consciousness, and to seek the possibility of utilizing the Rare Sugars. Fundamental statistical analysis and Hypothesis Testing analysis are executed based on that. Some interesting and instructive results were obtained.
\end{abstract}

Keywords: rare sugars, health, consumer, hypothesis testing

\section{Introduction}

The Rare Sugars' study has launched on $1980^{\text {th }}$ by Professor Takeshi Izumori (Kagawa Uni versity). The way to the mass production was developed by the method of enzymatic reaction. The International Society of Rare Sugars was established in 2001. Local government of Kagawa Prefecture comes to assist this research activity on this big innovation newly born in Kagawa Prefecture. The Rare Sugars have advantage that a blood-sugar level does not increase so much after eating, in spite of it being a sugar. And it also holds the upturn of the blood pressure. Therefore it is expected as a new functional material for the prevention of metabolic syndrome.

By the way, one kind of the Rare Sugar D-psicose has the following characteristics.

(1) a sweetening made by the natural starch

(2) non calorie and its sweetness is $70 \%$ to those of sugar

(3) organoleptic property of coolness and sharpness in taste

Many medical research papers are published on the Rare Sugars as follows.

Analysis of the function of D-psicose ; Hossain et al., 2011, Hayashi et al., 2010, Iida et al., 2010

Analysis of the function of D-allose ; Yamada et al., 2012, Kajikawa et al., 2010, Hirata et al., 2009

On the other hand, these are few papers analyzed by the viewpoint from consumers. Kondou(2017) has made a versatile survey on the development and prevailing activities mainly executed by the local government of Kagawa Prefecture in Japan, International Association of Rare Sugar, and The Rare Sugar Spreading Organization. The Rare Sugars is good for the health and is sold in the market as a sweetening, seasoning or functional ingredient for food. The Rare Sugars are prevailing in Japan by such activities as cooking class where the Rare Sugars are utilized for the new cuisine.

In this paper, a questionnaire investigation is executed to the student of Kagawa Junior College in order to clarify the recognition level among consumers and to pursue the future possibility of the Rare Sugars. Basic statistical analysis and Hypothesis Testing analysis are conducted. The nine issues are set and Hypothesis Testing analysis 
is executed.

The rest of this paper is organized as follows. In section 2, outline of the questionnaire investigation and its basic statistical results are exhibited. After that, Hypothesis Testing analysis is performed in section 3, which is followed by the remarks of section 4 .

\section{Outline and the Basic Statistical Results of the Questionnaire Research}

\subsection{Outline of the Questionnaire Research}

A questionnaire investigation is executed to the student of Kagawa Junior College in order to clarify the recognition level among consumers and to pursue the future possibility of the Rare Sugars. The outline of the questionnaire research is as follows. The questionnaire sheet is attached in Appendix.

(1) Scope of investigation :

Student of Kagawa Junior College

Period

Method

Collection
(1) April - June 2015, (2) April - June 2017

Leave until called for

Number of distribution (1) 186, (2) 335

Number of collection (1)186 (collection rate 100.0\%), (2) 335

(collection rate $100.0 \%$ )

Valid answer (1)186, (2) 333

\subsection{Basic Statistical Results}

Now, we show the main summary results by single variable.

(1) Basic characteristics of answerers

Q32 Sex

\begin{tabular}{lrr}
\hline & Frequency & $\%$ \\
\hline Male & 30 & 9.0 \\
Female & 303 & 91.0 \\
\hline Total & 333 & 100.0 \\
\hline
\end{tabular}

Q32 Sex

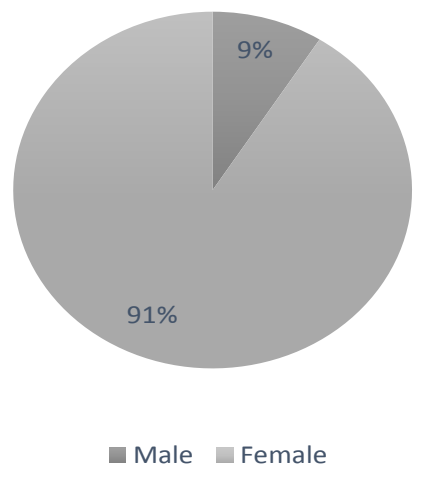

Q33 Age

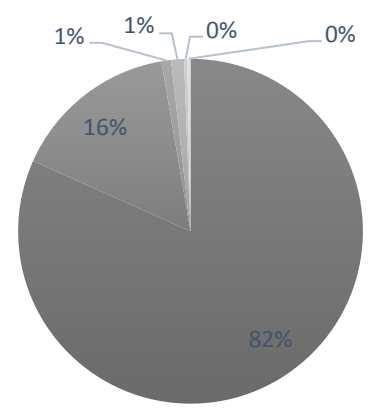

Q33 Age

\begin{tabular}{lrr}
\hline & Frequency & $\%$ \\
\hline-19 & 272 & 81.7 \\
$20-29$ & 52 & 15.6 \\
$30-39$ & 3 & 0.9 \\
$40-49$ & 4 & 1.2 \\
$50-59$ & 1 & 0.3 \\
$60-$ & 1 & 0.3 \\
\hline Total & 333 & 100.0 \\
\hline
\end{tabular}


Q34 Occupation

\begin{tabular}{lrr}
\hline & Frequency & $\%$ \\
\hline Student & 324 & 97.9 \\
Company Employee & 3 & 0.9 \\
Clerk of Organization & 1 & 0.3 \\
Housewife & 1 & 0.3 \\
Miscellaneous & 2 & 0.6 \\
\hline Total & 331 & 100.0 \\
\hline
\end{tabular}

\section{Q34 Occupation}

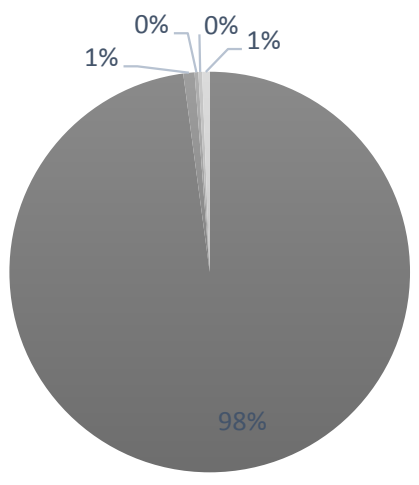

- Student

- Company Employee

- Clerk of Organization $\square$ Housewife

$\square$ Miscellaneous

(2) Summary results for the items used in Hypothesis Testing

Q8 Do you want to try to eat or drink the food in which the Rare Sugar is included?

\begin{tabular}{|c|c|c|c|c|c|c|}
\hline & $\begin{array}{c}\text { Think it } \\
\text { very much }\end{array}$ & $\begin{array}{l}\text { Slightly } \\
\text { think so }\end{array}$ & $\begin{array}{c}\text { Cannot say } \\
\text { either }\end{array}$ & $\begin{array}{l}\text { Slightly do } \\
\text { not think so }\end{array}$ & $\begin{array}{l}\text { Do not } \\
\text { think so }\end{array}$ & Total \\
\hline Frequency & 45 & 59 & 48 & 5 & 2 & 159 \\
\hline$\%$ & 28.3 & 37.1 & 30.2 & 3.1 & 1.3 & 100.0 \\
\hline \multicolumn{7}{|c|}{ Q15 I want to know how long I should use it in order to confirm the effectiveness. } \\
\hline Frequency & 53 & 109 & 112 & 44 & 14 & 332 \\
\hline$\%$ & 16.0 & 32.8 & 33.7 & 13.3 & 4.2 & 100.0 \\
\hline \multicolumn{7}{|c|}{ Q18 I cannot grasp the concrete effect. } \\
\hline Frequency & 82 & 118 & 82 & 33 & 17 & 332 \\
\hline$\%$ & 24.7 & 35.5 & 24.7 & 9.9 & 5.1 & 100.0 \\
\hline \multicolumn{7}{|c|}{ Q25 Do you take interest in a diet? } \\
\hline Frequency & 128 & 105 & 52 & 23 & 24 & 332 \\
\hline$\%$ & 38.6 & 31.6 & 15.7 & 6.9 & 7.2 & 100.0 \\
\hline \multicolumn{7}{|c|}{ Q26 Are you careful for the health? } \\
\hline Frequency & 44 & 127 & 127 & 23 & 10 & 331 \\
\hline$\%$ & 13.3 & 38.4 & 38.4 & 6.9 & 3.0 & 100.0 \\
\hline \multicolumn{7}{|c|}{ Q27 Do you take interest in the designated health food? } \\
\hline Frequency & 49 & 107 & 124 & 37 & 14 & 331 \\
\hline$\%$ & 14.8 & 32.3 & 37.5 & 11.2 & 4.2 & 100.0 \\
\hline
\end{tabular}


Q8 Do you want to try to eat or drink the food in which the Rare Sugar is included?

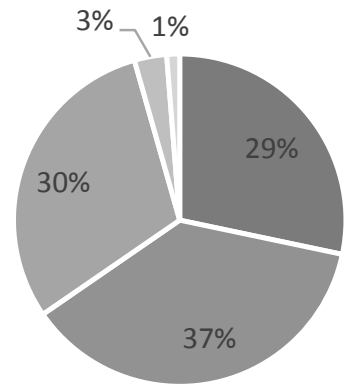

- Think it very much $\quad$ Slightly think so $\quad$ Cannot say either

- Slightly do not think so $₫$ Do not think so

Q15 I want to know how long I should use it in order to confirm the effectiveness.

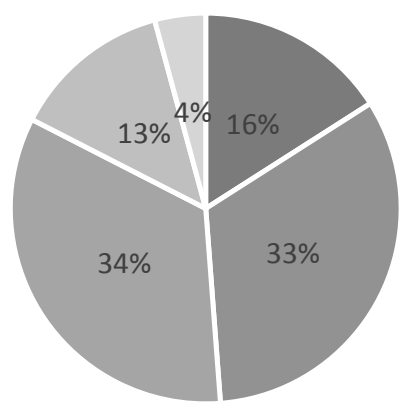

- Think it very much Slightly think so $\quad$ Cannot say either

- Slightly do not think so $\square$ Do not think so

Q18 I cannot grasp the concrete effect.

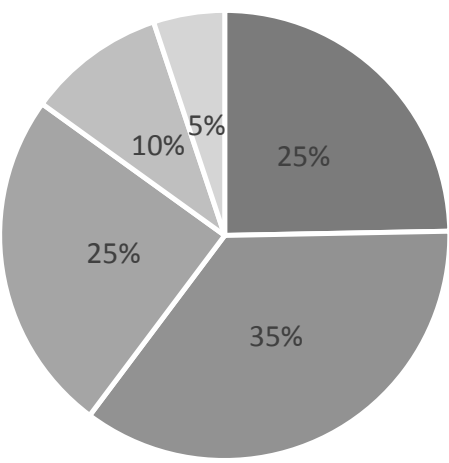

\footnotetext{
- Think it very much $\quad$ Slightly think so $\quad$ Cannot say either

- Slightly do not think so $₫$ Do not think so
} 


\section{Q25 Do you take interest in a diet?}

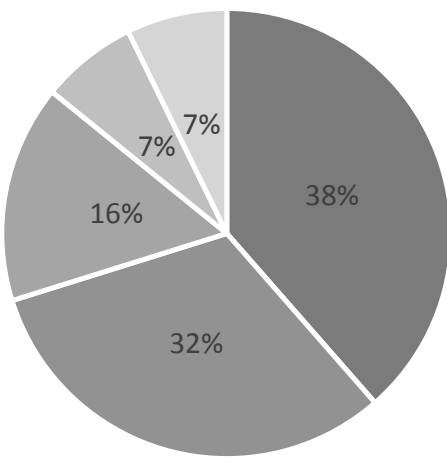

- Think it very much $\quad$ Slightly think so $\quad$ Cannot say either

- Slightly do not think so $₫$ Do not think so

\section{Q26 Are you careful for the health?}

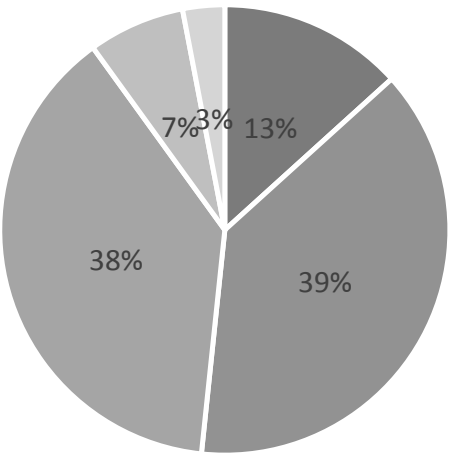

- Think it very much $\quad$ Slightly think so $\quad$ Cannot say either

- Slightly do not think so $\square$ Do not think so

\section{Q27 Do you take interest in the designated health} food?

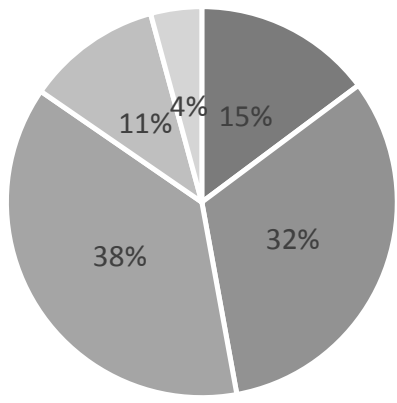

\footnotetext{
- Think it very much

- Slightly think so

- Cannot say either

= Slightly do not think so $=$ Do not think so
}

As the Rare Sugar is used in the cooking experiment in the Nutrition and Cooking Course at Kagawa Junior College, many students know its presence and its utility. But they also feel that the Rare Sugar is not so famous 
in society. Junior College students consists of the female students in majority, therefore they are conscious for the diet.

\section{Hypothesis Testing}

Hereinafter we make Hypothesis Testing analysis based upon the questionnaire investigation data.

(1) Setting Hypothesis

In the Hypothesis Testing analysis, nine issues are set as follows.

A-1) Those who want to try to eat or drink the food in which the Rare Sugar is included have interest in a diet.

A-2) Those who want to try to eat or drink the food in which the Rare Sugar is included are careful of his/her health.

A-3) Those who want to try to eat or drink the food in which the Rare Sugar is included have interest in the designated health food.

A-4) Those who want to know how long he/she should use it in order to confirm the effectiveness have interest in a diet.

A-5) Those who want to know how long he/she should use it in order to confirm the effectiveness are careful of his/her health.

A-6) Those who want to know how long he/she should use it in order to confirm the effectiveness have interest in the designated health food.

A-7) Those who cannot grasp the concrete effect have interest in a diet.

A-8) Those who cannot grasp the concrete effect are careful of his/her health.

A-9) Those who cannot grasp the concrete effect have interest in the designated health food.

Now, we set the following nine Null hypotheses.

A-1) There is not so much difference whether those who want to try to eat or drink the food in which the Rare Sugar is included have interest in a diet or not.

A-2) There is not so much difference whether those who want to try to eat or drink the food in which the Rare Sugar is included are careful of his/her health or not.

A-3) There is not so much difference whether those who want to try to eat or drink the food in which the Rare Sugar is included have interest in the designated health food or not.

A-4) There is not so much difference whether those who want to know how long he/she should use it in order to confirm the effectiveness have interest in a diet or not.

A-5) There is not so much difference whether those who want to know how long he/she should use it in order to confirm the effectiveness are careful of his/her health or not.

A-6) There is not so much difference whether those who want to know how long he/she should use it in order to confirm the effectiveness have interest in the designated health food or not.

A-7) There is not so much difference whether those who cannot grasp the concrete effect have interest in a diet or not.

A-8) There is not so much difference whether those who cannot grasp the concrete effect are careful of his/her health or not.

A-9) There is not so much difference whether those who cannot grasp the concrete effect have interest in the designated health food or not.

(2) Hypothesis Testing

The results of Hypothesis Testing analysis are as follows.

Null Hypothesis A-1): There is not so much difference whether those who want to try to eat or drink the food in which the Rare Sugar is included have interest in a diet or not.

Summary table for Null Hypothesis A-1) is exhibited in Table 1. Figure is also attached (Figure 1). 
Table 1. Summary table for Null Hypothesis A-1)

\begin{tabular}{|c|c|c|c|c|}
\hline $\begin{array}{c}\text { Do you take interest } \\
\text { in a diet? }\end{array}$ & \multicolumn{4}{|c|}{$\begin{array}{l}\text { Do you want to try to eat or drink the food } \\
\text { in which the Rare Sugar is included? }\end{array}$} \\
\hline \multirow{3}{*}{ Think so } & & & & $\frac{\text { lotal }}{109}$ \\
\hline & Frequency & $\begin{array}{r}80 \\
734\end{array}$ & $\begin{array}{r}29 \\
266\end{array}$ & $\begin{array}{r}109 \\
100.0\end{array}$ \\
\hline & $\frac{\%}{\text { Freguncy }}$ & $\begin{array}{r}73.4 \\
23\end{array}$ & $\begin{array}{r}26.6 \\
25\end{array}$ & $\begin{array}{r}100.0 \\
48\end{array}$ \\
\hline $\begin{array}{l}\text { Cannot say either/ } \\
\text { Do not think so }\end{array}$ & $\%$ & 47.9 & 52.1 & 100.0 \\
\hline \multirow{2}{*}{ Total } & Frequency & 103 & 54 & 157 \\
\hline & $\%$ & 65.6 & 34.4 & 100.0 \\
\hline
\end{tabular}

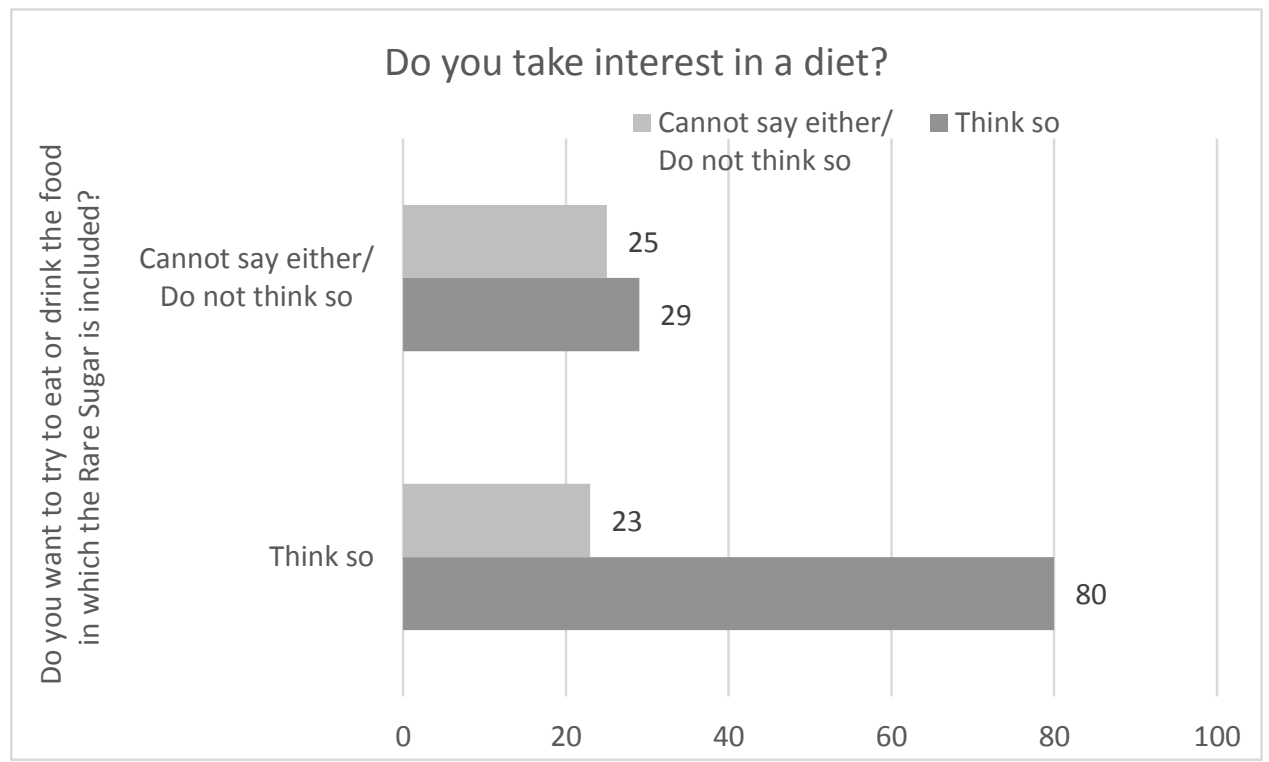

Figure 1. Summary for Null Hypothesis A-1)

The null hypothesis is rejected with $1 \%$ significance level. It can be said that those who want to try to eat or drink the food in which the Rare Sugar is included have interest in a diet.

Null Hypothesis A-2): There is not so much difference whether those who want to try to eat or drink the food in which the Rare Sugar is included are careful of his/her health or not.

Summary table concerning Null Hypothesis A-2) is exhibited in Table 2. Figure is also attached (Figure 2).

Table 2. Summary table for Null Hypothesis A-2)

\begin{tabular}{|c|c|c|c|c|}
\hline \multirow[t]{2}{*}{$\begin{array}{l}\text { Are you careful for } \\
\text { the health? }\end{array}$} & \multicolumn{4}{|c|}{$\begin{array}{l}\text { Do you want to try to eat or drink the food } \\
\text { in which the Rare Sugar is included? }\end{array}$} \\
\hline & & Think so & Do not think so & Total \\
\hline \multirow{2}{*}{ Think so } & Frequency & 65 & 21 & 86 \\
\hline & $\%$ & 75.6 & 24.4 & 100.0 \\
\hline \multirow{2}{*}{$\begin{array}{c}\text { Cannot say either/ } \\
\text { Do not think so }\end{array}$} & Frequency & 37 & 33 & 70 \\
\hline & $\%$ & 52.9 & 47.1 & 100.0 \\
\hline \multirow{2}{*}{ Total } & Frequency & 102 & 54 & 156 \\
\hline & $\%$ & 65.4 & 34.6 & 100.0 \\
\hline
\end{tabular}




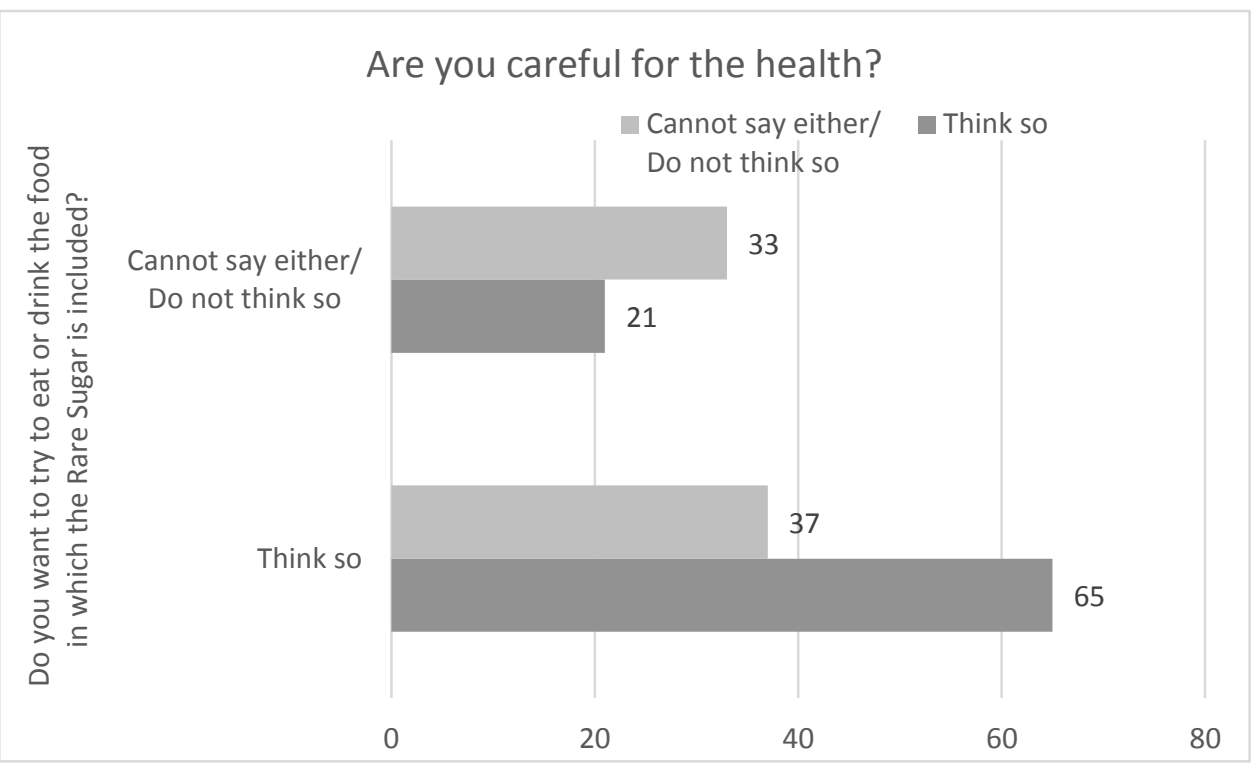

Figure 2. Summary for Null Hypothesis A-2)

The null hypothesis is rejected with $1 \%$ significance level. It can be said that those who want to try to eat or drink the food in which the Rare Sugar is included are careful of his/her health.

Null Hypothesis A-3): There is not so much difference whether those who want to try to eat or drink the food in which the Rare Sugar is included have interest in the designated health food or not.

Summary table concerning Null Hypothesis A-3) is exhibited in Table 3. Figure is also attached (Figure 3).

Table 3. Summary table for Null Hypothesis A-3)

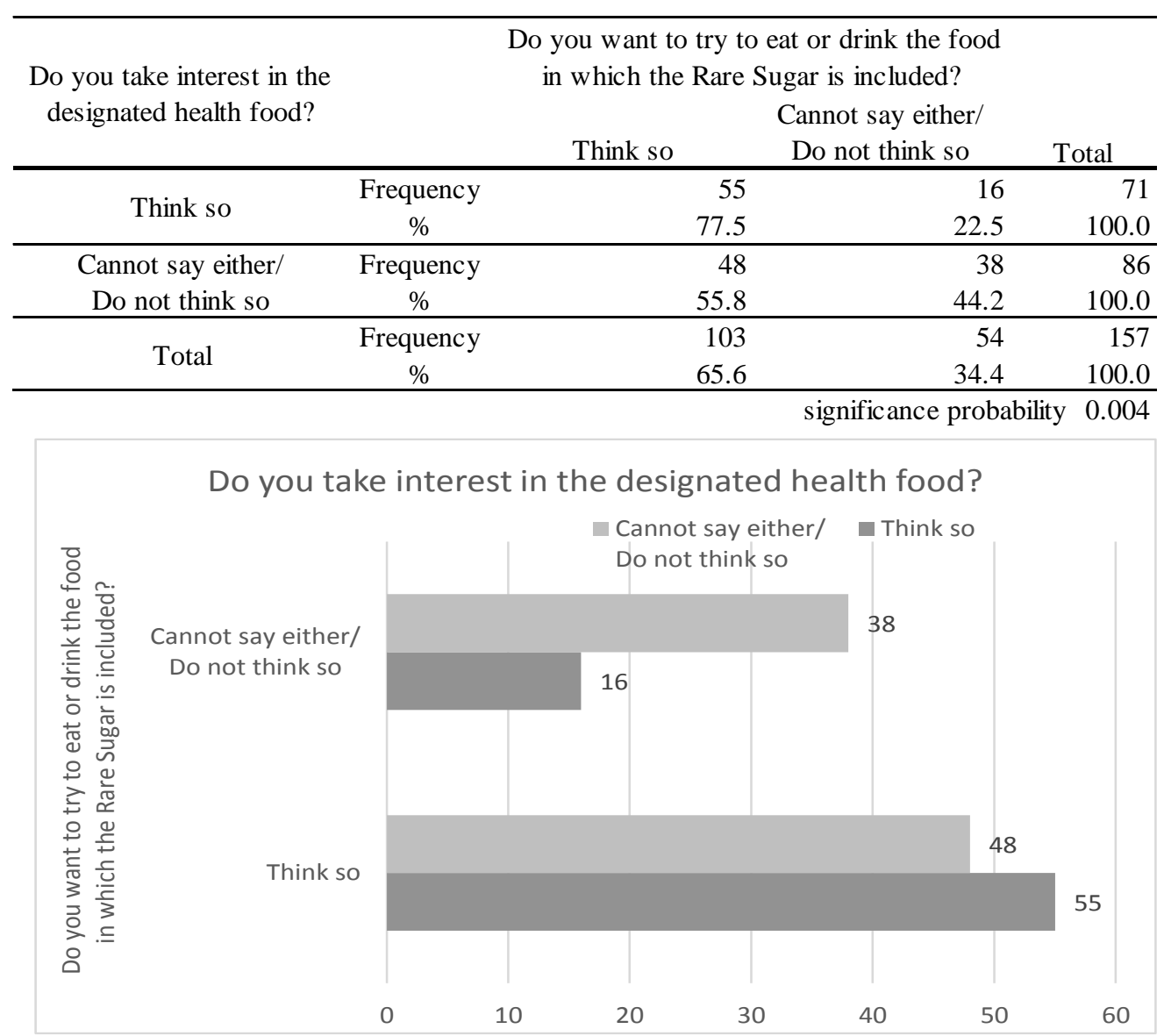

Figure 3. Summary for Null Hypothesis A-3) 
The null hypothesis is rejected with $1 \%$ significance level. It can be said that those who want to try to eat or drink the food in which the Rare Sugar is included have interest in the designated health food.

Null Hypothesis A-4): There is not so much difference whether those who want to know how long he/she should use it in order to confirm the effectiveness have interest in a diet or not.

Summary table concerning Null Hypothesis A-4) is exhibited in Table 4. Figure is also attached (Figure 4).

Table 4. Summary table for Null Hypothesis A-4)

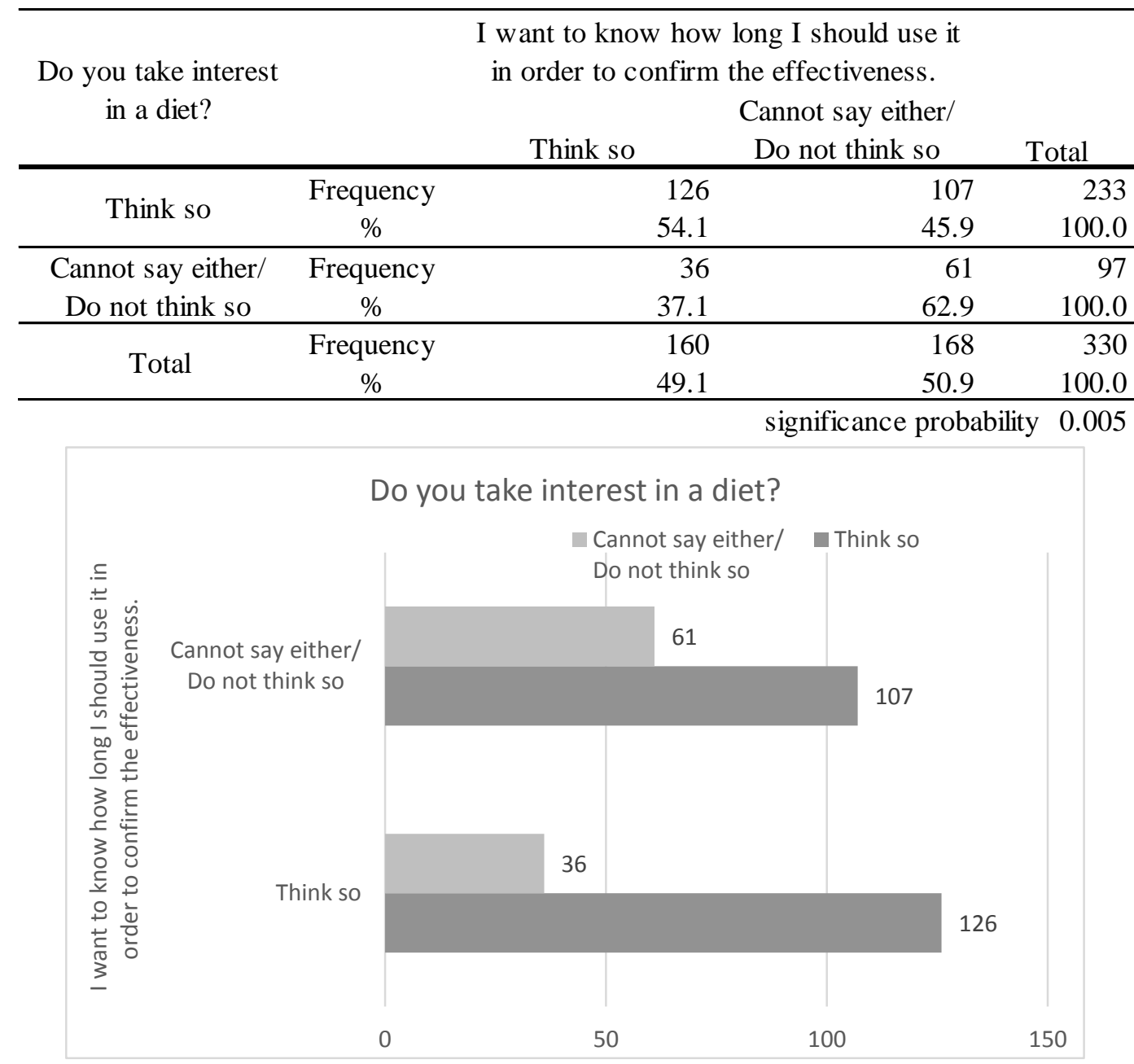

Figure 4. Summary for Null Hypothesis A-4)

The null hypothesis is rejected with $1 \%$ significance level. It can be said that those who want to know how long he/she should use it in order to confirm the effectiveness have interest in a diet.

Null Hypothesis A-5): There is not so much difference whether those who want to know how long he/she should use it in order to confirm the effectiveness are careful of his/her health or not.

Summary table concerning Null Hypothesis A-5) is exhibited in Table 5. Figure is also attached (Figure 5). 
Table 5. Summary table for Null Hypothesis A-5)

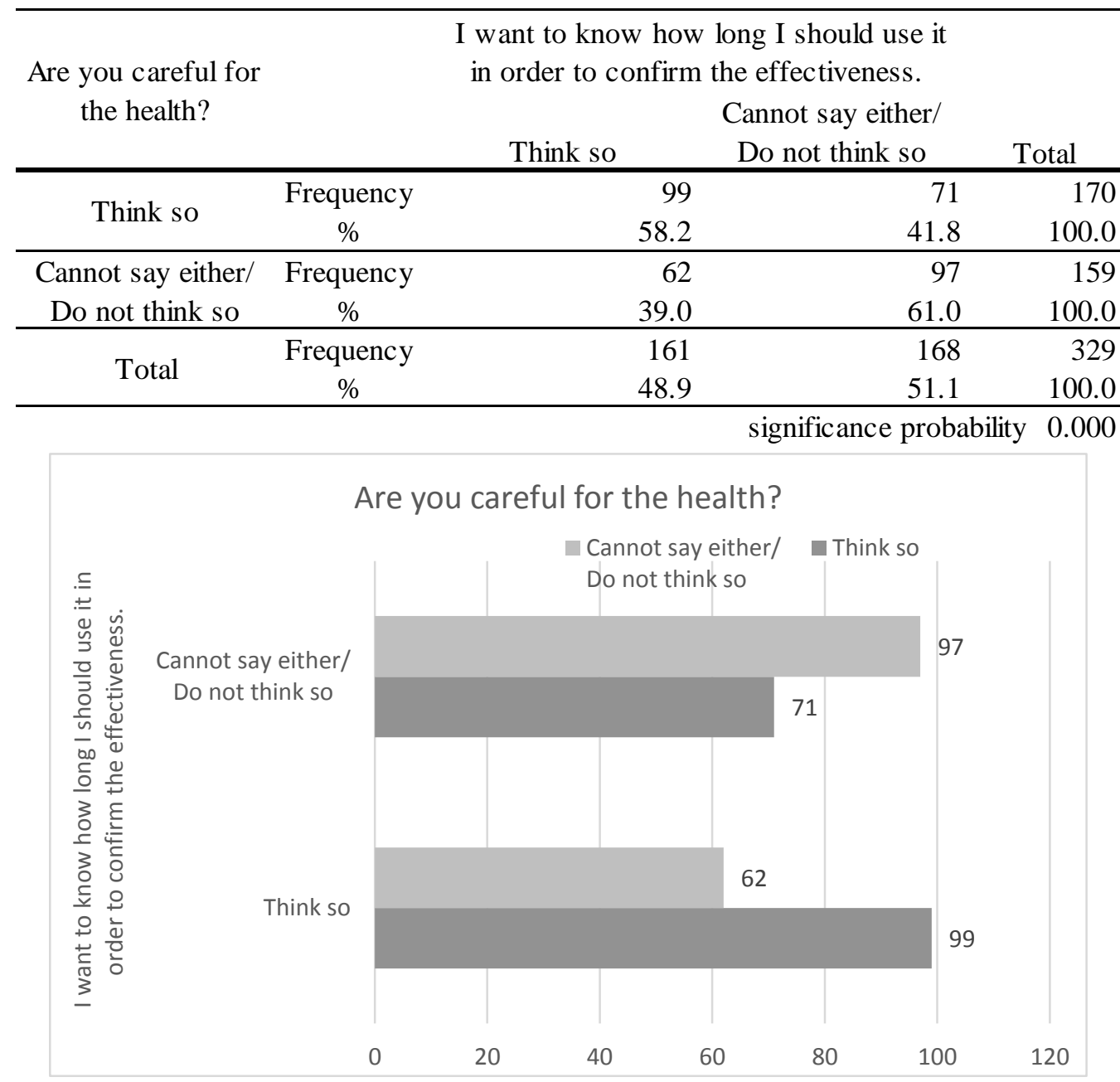

Figure 5. Summary for Null Hypothesis A-5)

The null hypothesis is rejected with $1 \%$ significance level. It can be said that those who want to know how long he/she should use it in order to confirm the effectiveness are careful of his/her health.

Null Hypothesis A-6): There is not so much difference whether those who want to know how long he/she should use it in order to confirm the effectiveness have interest in the designated health food or not.

Summary table concerning Null Hypothesis A-6) is exhibited in Table 6. Figure is also attached (Figure 6).

Table 6. Summary table for Null Hypothesis A-6)

\begin{tabular}{|c|c|c|c|c|}
\hline \multirow[t]{2}{*}{$\begin{array}{l}\text { Do you take interest in the } \\
\text { designated health food? }\end{array}$} & \multicolumn{4}{|c|}{$\begin{array}{l}\text { I want to know how long I should use it } \\
\text { in order to confirm the effectiveness. } \\
\text { Cannot say either/ }\end{array}$} \\
\hline & & Think so & Do not think so & Total \\
\hline \multirow{2}{*}{ Think so } & Frequency & 89 & 66 & 155 \\
\hline & $\%$ & 57.4 & 42.6 & 100.0 \\
\hline \multirow{2}{*}{$\begin{array}{l}\text { Cannot say either/ } \\
\text { Do not think so }\end{array}$} & Frequency & 72 & 102 & 174 \\
\hline & $\%$ & 41.4 & 58.6 & 100.0 \\
\hline \multirow{2}{*}{ Total } & Frequency & 161 & 168 & 329 \\
\hline & $\%$ & 48.9 & 51.1 & 100.0 \\
\hline
\end{tabular}




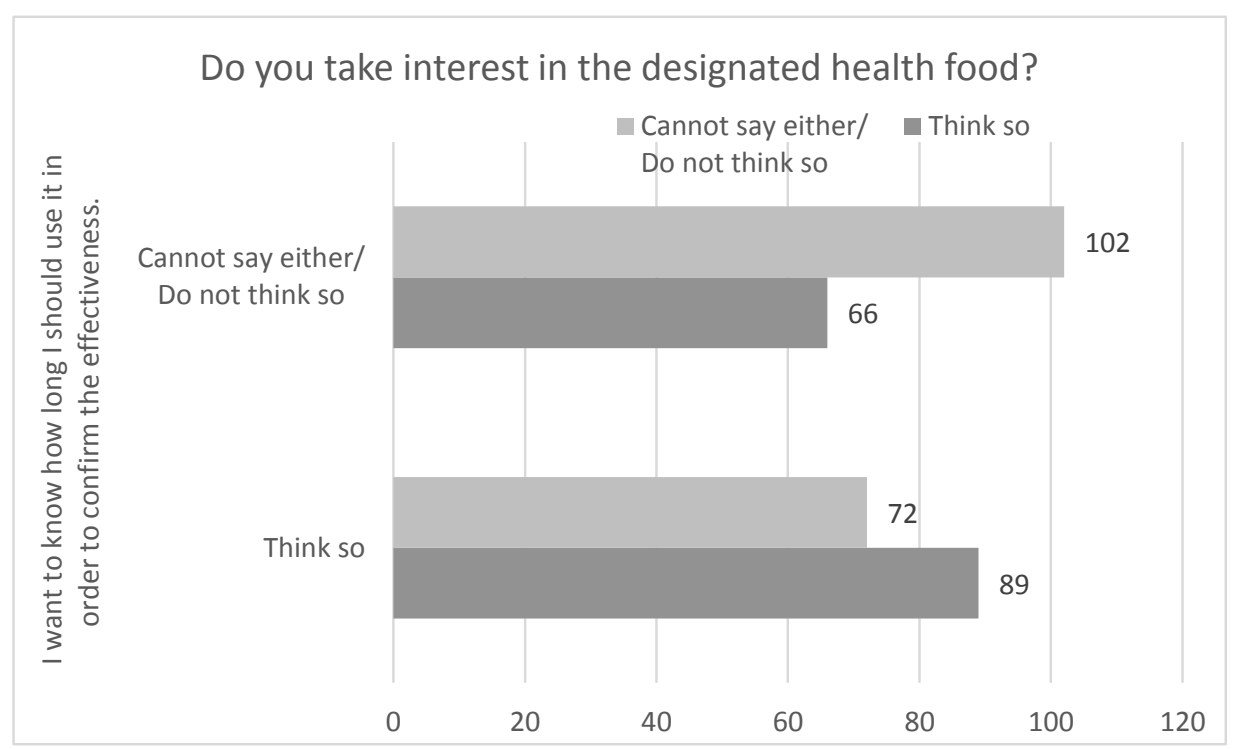

Figure 6. Summary for Null Hypothesis A-6)

The null hypothesis is rejected with $1 \%$ significance level. It can be said that those who want to know how long he/she should use it in order to confirm the effectiveness have interest in the designated health food.

Null Hypothesis A-7): There is not so much difference whether those who cannot grasp the concrete effect have interest in a diet or not.

Summary table concerning Null Hypothesis A-7) is exhibited in Table 7. Figure is also attached (Figure 7).

Table 7. Summary table for Null Hypothesis A-7)

\begin{tabular}{ccrrr}
\hline $\begin{array}{c}\text { Do you take interest } \\
\text { in a diet? }\end{array}$ & & I cannot grasp the concrete effect. \\
& & \multicolumn{2}{c}{$\begin{array}{c}\text { Cannot say either/ } \\
\text { Do not think so }\end{array}$} & Total \\
\hline \multirow{2}{*}{ Think so } & Think so & & 85 & 232 \\
& $\%$ & 147 & 36.6 & 100.0 \\
\hline Cannot say either/ & Frequency & 63.4 & 45 & 98 \\
Do not think so & $\%$ & 53 & 45.9 & 100.0 \\
\hline \multirow{2}{*}{ Total } & Frequency & 54.1 & 130 & 330 \\
& $\%$ & 200 & 39.4 & 100.0 \\
\hline & & 60.6 & significance probability & 0.115
\end{tabular}

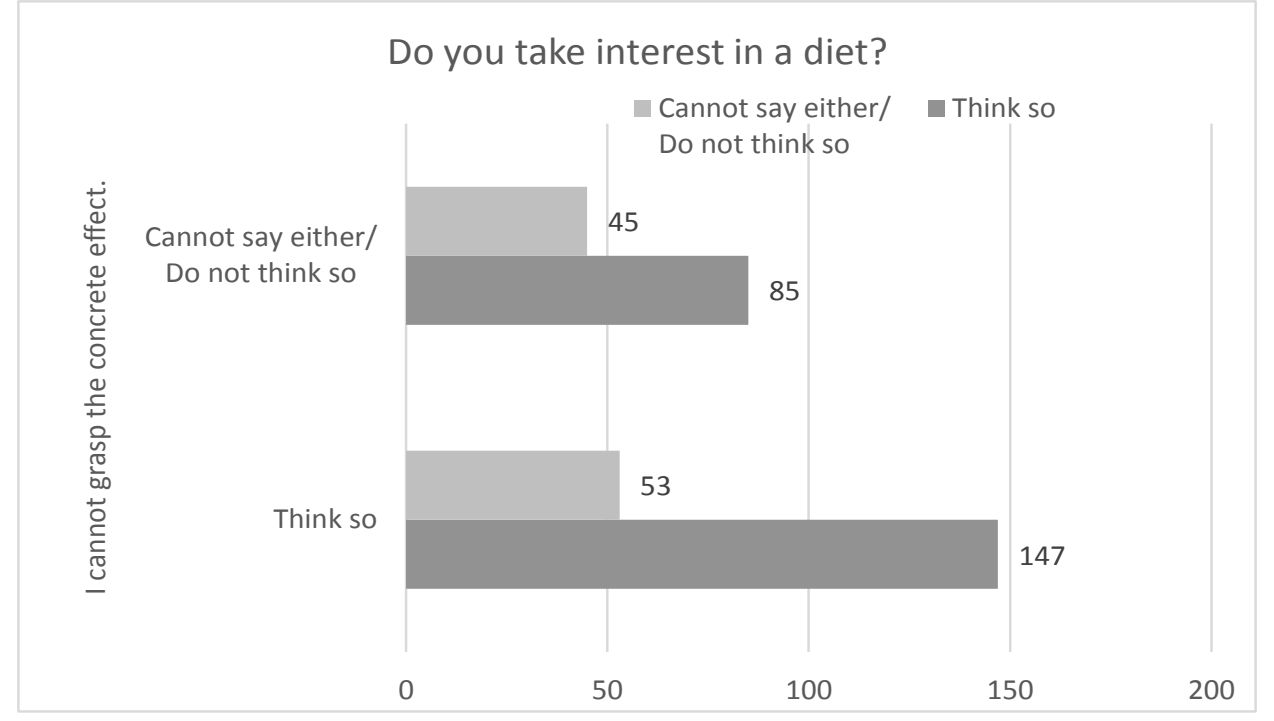

Figure 7. Summary for Null Hypothesis A-7) 
The null hypothesis is not rejected. It can be said that there is not so much difference whether those who cannot grasp the concrete effect have interest in a diet or not.

Null Hypothesis A-8): There is not so much difference whether those who cannot grasp the concrete effect are careful of his/her health or not.

Summary table concerning Null Hypothesis A-8) is exhibited in Table 8. Figure is also attached (Figure 8).

Table 8. Summary table for Null Hypothesis A-8)

\begin{tabular}{|c|c|c|c|c|}
\hline \multirow[t]{2}{*}{$\begin{array}{l}\text { Are you careful for } \\
\text { the health? }\end{array}$} & \multicolumn{4}{|c|}{ I cannot grasp the concrete effect. } \\
\hline & & Think so & Do not think so & Total \\
\hline \multirow{2}{*}{ Think so } & Frequency & 110 & 59 & 169 \\
\hline & $\%$ & 65.1 & 34.9 & 100.0 \\
\hline \multirow{2}{*}{$\begin{array}{c}\text { Cannot say either/ } \\
\text { Do not think so }\end{array}$} & Frequency & 89 & 71 & 160 \\
\hline & $\%$ & 55.6 & 44.4 & 100.0 \\
\hline \multirow{2}{*}{ Total } & Frequency & 199 & 130 & 329 \\
\hline & $\%$ & 60.5 & 39.5 & 100.0 \\
\hline
\end{tabular}

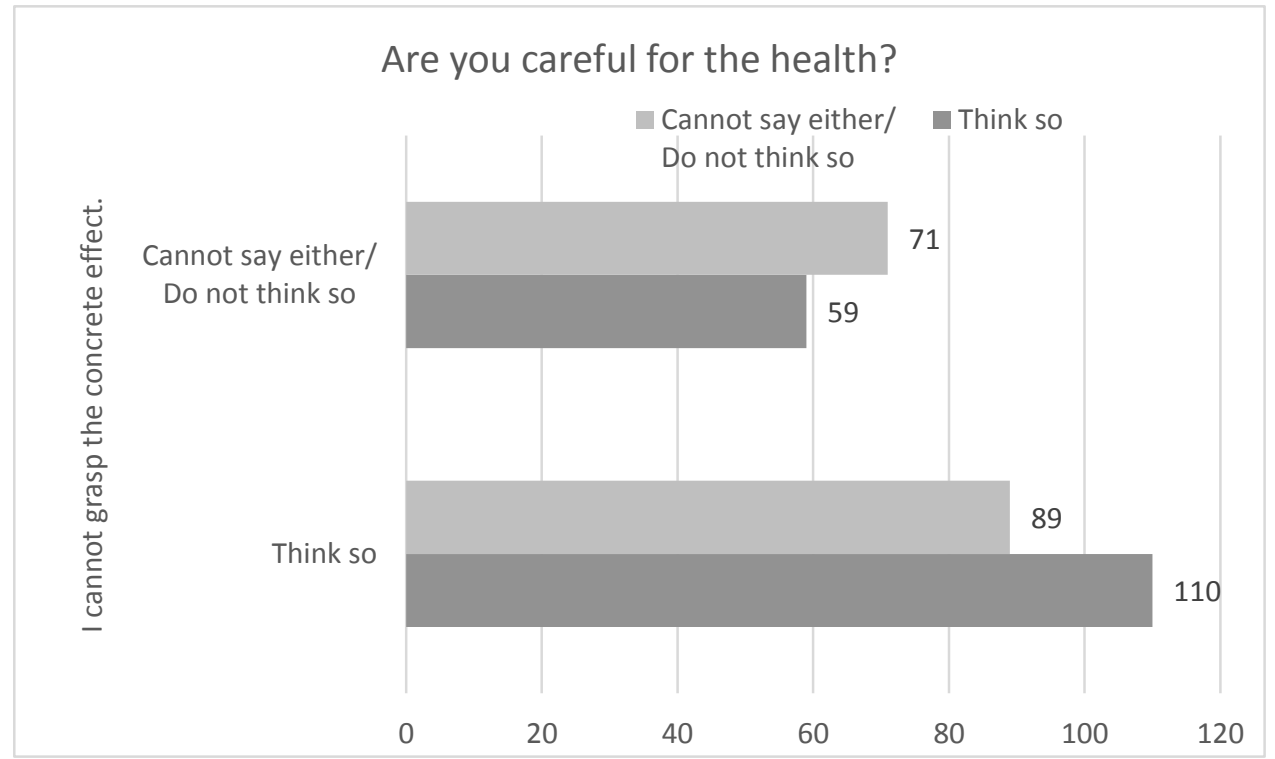

Figure 8. Summary for Null Hypothesis A-8)

The null hypothesis is not rejected. It can be said that there is not so much difference whether those who cannot grasp the concrete effect are careful of his/her health or not.

Null Hypothesis A-9): There is not so much difference whether those who cannot grasp the concrete effect have interest in the designated health food or not.

Summary table concerning Null Hypothesis A-9) is exhibited in Table 9. Figure is also attached (Figure 9).

Table 9. Summary table for Null Hypothesis A-9)

\begin{tabular}{|c|c|c|c|c|}
\hline \multirow{2}{*}{$\begin{array}{l}\text { Do you take interest in t } \\
\text { designated health food }\end{array}$} & \multicolumn{4}{|c|}{ I cannot grasp the concrete effect. } \\
\hline & & Think so & Do not think so & Total \\
\hline \multirow{2}{*}{ Think so } & Frequency & 98 & 57 & 155 \\
\hline & $\%$ & 63.2 & 36.8 & 100.0 \\
\hline \multirow{2}{*}{$\begin{array}{c}\text { Cannot say either/ } \\
\text { Do not think so }\end{array}$} & Frequency & 102 & 72 & 174 \\
\hline & $\%$ & 58.6 & 41.4 & 100.0 \\
\hline \multirow{2}{*}{ Total } & Frequency & 200 & 129 & 329 \\
\hline & $\%$ & 60.8 & 39.2 & 100.0 \\
\hline
\end{tabular}




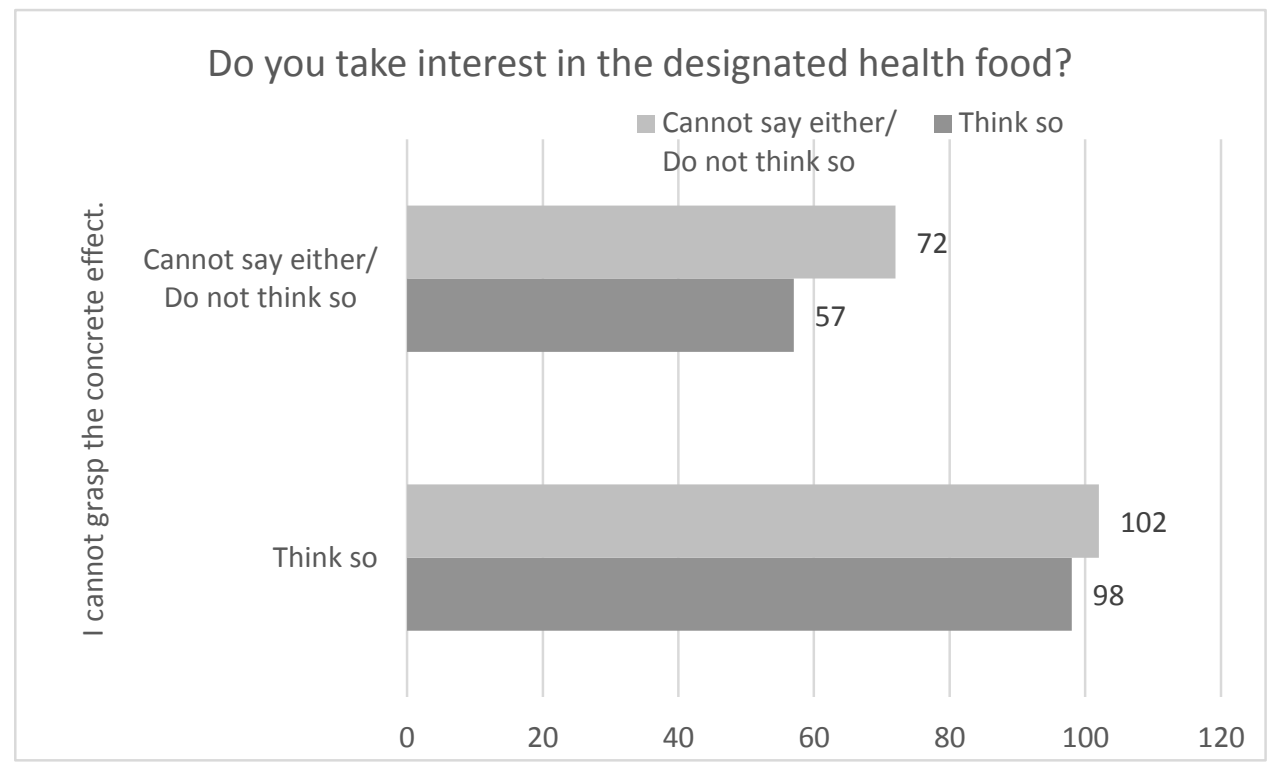

Figure 9. Summary for Null Hypothesis A-9)

The null hypothesis is not rejected. It can be said that there is not so much difference whether those who cannot grasp the concrete effect have interest in the designated health food or not.

\section{Remarks}

As the Rare Sugar is used in the cooking experiment in the Nutrition and Cooking Course at Kagawa Junior College, many students know its presence and its utility. But they also feel that the Rare Sugar is not so famous in society. Junior College students consists of the female students in majority, therefore they are conscious for the diet.

The results for Hypothesis Testing analysis are as follows. 6 cases out of 9 are rejected (A-1, A-2, A-3, A-4, A-5, A-6). It can be said that the majority of issues are insisted clearly.

\section{Conclusion}

The Rare Sugars exist naturally and have many kinds (more than 50). They have good effect for health such as prevention of increasing the blood - sugar level after eating, suppression of fat accumulation, suppression of increasing the blood pressure, and anti-oxidative effect etc. It is in the spotlight for many people especially for those who are in the metabolic syndrome. The Rare Sugars are prevailing in Japan by such activities as cooking class where the Rare Sugars are utilized for the new cuisine. There are few related papers concerning the marketing research and its utilization of this matter. In this paper, a questionnaire investigation was executed to the student of Kagawa Junior College in order to clarify consumers' current condition and their consciousness, and to seek the possibility of utilizing the Rare Sugars. Hypothesis Testing analysis was conducted based on that. We have set nine issues as follows.

A-1) Those who want to try to eat or drink the food in which the Rare Sugar is included have interest in a diet.

A-2) Those who want to try to eat or drink the food in which the Rare Sugar is included are careful of his/her health.

A-3) Those who want to try to eat or drink the food in which the Rare Sugar is included have interest in the designated health food.

A-4) Those who want to know how long he/she should use it in order to confirm the effectiveness have interest in a diet.

A-5) Those who want to know how long he/she should use it in order to confirm the effectiveness are careful of his/her health.

A-6) Those who want to know how long he/she should use it in order to confirm the effectiveness have interest in the designated health food.

A-7) Those who cannot grasp the concrete effect have interest in a diet.

A-8) Those who cannot grasp the concrete effect are careful of his/her health. 
A-9) Those who cannot grasp the concrete effect have interest in the designated health food.

The results for Hypothesis Testing analysis are as follows. 6 cases out of 9 are rejected (A-1, A-2, A-3, A-4, A-5, A-6). It can be said that the majority of issues are insisted clearly.

Although it has a limitation that it is restricted in the number of research, we could obtain the fruitful results.

Further study on this should be executed such as multivariate analysis. Various cases should be investigated here after.

\section{Acknowledgements}

The authors are grateful to all those who supported us for answering the questionnaire investigation.

\section{References}

Hayashi, N., Iida, T., Yamada, T., Okuma, K., Takehara, I., Yamamoto, T., ... Tokuda, M. (2010). Study on the postprandial blood glucose suppression effect of D-psicose in borderline diabetes and the safety of long-term ingestion by normal human subjects. Biosci Biotechnol Biochem., 74(3), 510-519. https://doi.org/10.1271/bbb.90707

Hirata, Y., Saito, M., Tsukamoto, I., Yamaguchi, F., Sui, L., Kamitori, K., ... Tokuda, M. (2009 May). Analysis of the inhibitory mechanism of D-allose on MOLT-4F leukemia cell proliferation. J Biosci Bioeng., 107(5), 562-568. https://doi.org/10.1016/j.jbiosc.2008.12.021

Hossain, M. A., Kitagaki, S., Nakano, D., Nishiyama, A., Funamoto, Y., Matsunaga, T., ... Tokuda, M. (2011 Feb 4). Rare sugar D-psicose improves insulin sensitivity and glucose tolerance in type 2 diabetes Otsuka Long-Evans Tokushima Fatty (OLETF) rats. Biochem Biophys Res Commun, 405(1), 7-12. https://doi.org/10.1016/j.bbrc.2010.12.091

Iida, T., Hayashi, N., Yamada, T., Yoshikawa, Y., Miyazato, S., Kishimoto, Y., ... Izumori, K. (2010). Failure of d-psicose absorbed in the small intestine to metabolize into energy and its low large intestinal fermentability in humans. Metabolism, 59(2), 206-214. https://doi.org/10.1016/j.metabol.2009.07.018

Kajikawa, T., Tada, S., Kitanaka, A., Tokuda, M., Taminat, T., \& Analy, J. (2010). Reactivity of rare sugar D-allose during glycation of human serum albumin. Bio-Sci., 33(3), 227-236.

Kondou, K. (2017). The Present Situation of Industrialization and the Future Development on Rare Sugars, Bulletin of Kagawa Junior College, 45, 363-371.

Yamada, K., Noguchi, C., Kamitori, K., Dong, Y., Hirata, Y., Hossain, M. A., .. Yamaguchi, F. (2012 Feb). Rare sugar d-allose strongly induces thioredoxin-interacting protein and inhibits osteoclast differentiation in Raw264 cells. Nutr Res, 32(2), 116-123. https://doi.org/10.1016/j.nutres.2011.12.010 
Appendix. Questionnaire about the Rare Sugars

\section{$\checkmark$ Questionnaire about the Rare Sugars}

The Rare Sugars exist naturally and have many kinds (morethan 50). They have good effect for health such as prevention of increasing the a blood-sugar level after eating, suppression of fat accumulation, suppression of increasing the blood pressure, and antioxidative effect etc. It is in the spotlight for many people especially for those who are in the metabolic syndrome.

Please select the appropriate item in each column.(Plural answers are allowed for Q2, 9, 24, 28. Select (1) (5) in the right colum for Q7, 8, 10-23, 25-27.)

1.We ask you about the Rare Sugars.

1-1. Do you know the Rare Sugars?

Q1 (1)Know (2)Do not know ( $\Rightarrow$ Proceed to Q8 who has selected (2) and answer until to the last.)

1-2. We ask you who have selected (1). Where did you know the Rare Sugar?【Plural answers are allowed】

Q2 (1)TV (2)Magazine (3)Newspaper (4)Shop (5)Vending Machine (6)Seminar (7)Internet (8)Hear from another person (9)Miscellaneous( )

1-3. Do you know that the Rare Sugar has effect on obese prevention and/or diabetes prevention etc.?

Q3 (1)Know (2)Do not know

1-4. Have you heard or used the syrup which includes Rare Sugar "Rare Sugar Sweet"?

Q4 (1)Heard (2)Not heard

Q5 (1)Used (2)Not used

1-5. Have you drunk or eaten the food which includes the Rare Sugar?

Q6 (1)Yes (2) No

\begin{tabular}{l|lll||l|l|l|l|l|l|l|l} 
Q7 1-6. We ask you who have selected (1) in Q6. Was the Rare Sugar effective after using it for more than one & (1)Think it & (2)Slightly & (3)Cannot & (4)Slightly do & (5)Do not \\
think
\end{tabular}

Q7 month? ( $\Rightarrow$ Proceed to Q9)

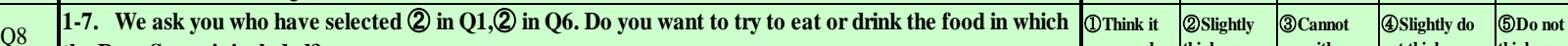
the Rare Sugar is included?

1-8. What kind of food do you want to eat if the Rare Sugar is included?【Plural answers are allowed】

Q9 (1)Cake (2)Juice (3)Japanese food (4)Western food (5)Chinese food (6)Miscellaneous ( 1-9.How do you want to use the Rare Sugar?

Q10 a. I want to use it in the cooking.

Q11 b. I can easily use it if there is a recipe.

Q12 c. I want to know where I can buy it because I want to use it as a seasoning.

Q13 d. I want to know where I can get information because I want to use it as a supplement.

Q14 e. I want to know the hospital where the Rare Sugar is used as a tool for treatment.

Q15 f. I want to know how long I should use it in order to confirm the effectiveness.

1-10.Do you have a question(doubt) or anxiety for the Rare Sugar?

Q16 a. It is not so popular.

Q17 b. It seems to be expensive.

Q18 c. I cannot grasp the concrete effect.

Q19 d. I cannot have confidence that it is safe for anybody.

Q20 e. Surrounding people do not use it so often.

Q21 f. I cannot find the food in the shop in which the Rare Sugar is included.

Q22 g. I cannot guess how I should use the Rare Sugar to what kind of cooking?

Q23 h. Miscellaneous(

1-11.Choose the drink that you are interested in.【Plural answers are allowed】

Q24 (1)aojiru (2)OS-1(oral rehydration solutionDrink for sports) (4)designated health drink (5)drink with the Rare Sugar (6)None (7)Miscellaneous (

Q25 1-12. Do you take interest in a diet?

Q26 1-13. Are you careful for the health?

Q27 1-14. Do you take interest in the designated health food?

1-15. Which method would be suitable for the Rare Sugar to become popular?

(1)TV CM (2)Use Twitter,Facebook (3)Advertisement by the company (4)Spread the way of cooking (5)Sell candy with the Rare Sugar

Q28 (6) Sell juice with the Rare Sugar (7)Restaurant at which the Rare Sugar is used in the cooking (8) Use it in the food at the hospital (9)Sell it as a supplement (10)Make promotion by utilizing famous sportsmen or entertainers (11)Miscellaneous (

2. What is your hobby? (Select only one in the right hand column)

Q29 2-1.Playing Sports: (1)Baseball (2)Football (3)Tennis (4)Golf (5)Miscellaneous (

Q30 2-2. Watching Sports: (1)Baseball (2)Football (3)Tennis (4)Golf (5)Miscellaneous (

)

2-3. Drinking: (1)Beer (2)Wine (3)Japanese wine-sake (4)Japanese liquor-shochu (5)Whisky

Q31 6)Miscellaneous ( )

\begin{tabular}{||l|l|l|l|l|}
\hline $\begin{array}{l}\text { 1)ike it } \\
\text { very much }\end{array}$ & $\begin{array}{l}\text { 2) Slightly } \\
\text { like it }\end{array}$ & $\begin{array}{l}\text { 3) Ordinary } \\
\text { level }\end{array}$ & & \\
\hline $\begin{array}{l}\text { 1) Like it } \\
\text { very much }\end{array}$ & $\begin{array}{l}\text { 2) Slightly } \\
\text { like it }\end{array}$ & $\begin{array}{l}\text { 3) Ordinary } \\
\text { level }\end{array}$ & & \\
\begin{tabular}{|l} 
1) Like it \\
very much
\end{tabular} & $\begin{array}{l}\text { 2)Slightly } \\
\text { like it }\end{array}$ & $\begin{array}{l}\text { (3)Ordinary } \\
\text { level }\end{array}$ & & \\
\hline
\end{tabular}




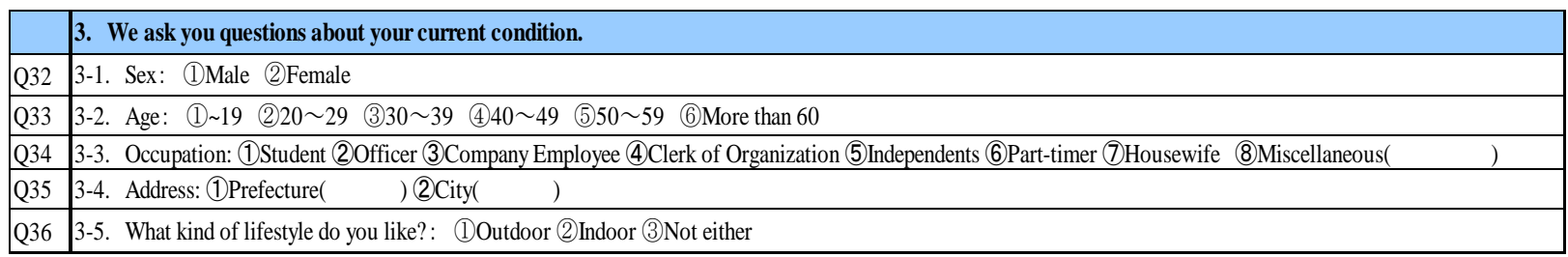

\section{Copyrights}

Copyright for this article is retained by the author(s), with first publication rights granted to the journal.

This is an open-access article distributed under the terms and conditions of the Creative Commons Attribution license (http://creativecommons.org/licenses/by/4.0/). 